\title{
A histological study on the effect of imatinib on the rats' testis after early postnatal exposure
}

\author{
L.I. Al-Allaf $\odot$ and H.A. Al-Ashoo \\ Department of Anatomy, College of Medicine, University of Mosul, Mosul, Iraq
}

\begin{tabular}{l} 
Article information \\
\hline Article history: \\
Received December 01, 2019 \\
Accepted January 20, 2020 \\
Available online November 1, 2020 \\
\hline Keywords: \\
Imatinib \\
Testes \\
Histopathology \\
Rats \\
\\
\hline Correspondence: \\
L.I. Al-Allaf \\
lumaallaf1971@ yahoo.com
\end{tabular}

DOI: 10.33899/ijvs.2020.126342.1303, (C2021, College of Veterinary Medicine, University of Mosul.

This is an open access article under the CC BY 4.0 license (http://creativecommons.org/licenses/by/4.0/).

\section{Introduction}

Malignancy is the second dominant reason of mortalities all over the world. Although cancer commonly affects people after they have completed their families, a serious minority are diagnosed at a younger age (1). In spite of the fact that the incidence of cancer in children all over the world is low, the age-optimized frequency is seventy to 160 newly diagnosed cases for each millions of children per year at the age of zero to 14 (2). These patients have to complaint not only with the effect of having cancer and the immediate complications of treatment, but also with the possibility that surgery, radiotherapy or chemotherapy may lead to temporary or permanent squeal as gonadal damage, infertility, and organs toxicity $(3,4)$. Imatinib $\left(1^{\text {st }}\right.$ generation Tyrosine kinase inhibitors (TKIs)) is a recent anticancer agent that is strongly inhibited human BCR-ABL1-positive tumor $(5,6)$, that make it a particularly suitable well planned 
agent for the treatment CML and ALL. Imatinib also induced an inhibitory action on the expression of c-Kit -TK receptors in the alimentary tract which is contributed in the pathogenesis of gastrointestinal stromal tumor-GIST $(7,8)$.

In addition, imatinib induces an inhibition to the PDGF$\alpha$ and PDGF- $\beta$ receptors (9) which may allow more therapeutic using. The major adverse effects enroll severe neutropenia and thrombocytopenia, oedema, fluid retention, nausea, mild diarrhoea, skin rashes, arthralgia, myalgia, bone pain, acute renal failure $(10,11)$, and hepatotoxicity (12). The safety margin of imatinib, and liability to induce organ toxicity, has been studied in a conflicting manner in current years (13). There is a report of the GIST patient or CML patient (males) suffered from with gynaecomastia and hydrocele following exposure to imatinib mesylate (14). Little is known about the effect of early exposure to imatinib. This work aims to evaluate the repercussion of exposure (in vivo) of male albino rats to imatinib mesylate (at neonatal or infantile periods) using histological analysis of their testes in several end points and in adulthood using rat which is preferred as a suitable and an attractive alternate animal model for human.

\section{Materials and methods}

This experimental work was conducted on rats (male albino) purchased from Animal House of Veterinary College, university of Mosul, Mosul, Iraq.

Throughout the investigations the rats were breed under controlled normal environmental laboratory conditions and animal facility and were housed in an air-conditioned room with 12-hours light and dark cycles, where the temperature $23 \pm 2^{\circ} \mathrm{C}$ and relative humidity $66-71 \%$ were kept stable. They were put in an individual manner in plastic cages (England) measuring $47 \times 34 \times 18 \mathrm{~cm}$ lined with wood chips (15) provided from Animal House. Animals were let to be comfort for a ten days before any procedure was performed (16), and supplied with free access of water ad libitum and pelleted standardized food (commercial rodent chow) (17). All rats received humane care, and procedures enrolling animals and their care were conducted in conformity with international roles and programs and the articles on animals accepted. The experiments were performed during the light section $(18,19)$.

Animals were randomly assigned. Intact pups exposed to oral imatinib (Glivec ${ }^{\circledR}$, STI 571; Novartis- purchased from Ibn-Sena Teaching Hospital, Mosul) at neonatal and early infantile period on PND 1 to PND10 $(n=32)$ using gavage with 24 gage needle and they were represented the treated group. They were received imatinib $200 \mathrm{mg} / \mathrm{kg}$ once daily for 10 days starting from PND 1 to PND10. While control group includes age and weight matched pup which received D. W following the same program applied to imatinib group $(\mathrm{n}=4$ for each). Each treated pup was observed for clear signs of toxicity for the next four hours, and mortality throughout the next 24 hours (20).

Imatinib doses choosen were justified to be in accordance with those used in clinical treatment regimens (21) (400-800 $\mathrm{mg} / \mathrm{d}$ or $340-590 \mathrm{mg} / \mathrm{m} 2$ as the weight is $70 \mathrm{~kg}$ ) dose surface area according to body-weight, $\mathrm{f} \times \mathrm{mg} / \mathrm{kg}=\mathrm{mg} / \mathrm{m} 2$, $\mathrm{f}$ is a factor equaling to 6.0 in rats (22).

Pups were categorized into 4 subgroups, according to the ages of euthanasia: 15 days postpartum $(n=8)$; 40days postpartum $(\mathrm{n}=8) ; 70$ days postpartum $(\mathrm{n}=8)$ and 140 days postpartum $(\mathrm{n}=8)(18)$.

Euthanization of rat with ether $(19,23)$ was done $24 \mathrm{~h}$ after the final dose was given at laboratory of postgraduate studies of Department of Anatomy, Nineveh College of Medicine, University of Nineveh, Mosul, Northern Iraq.

After longitudinal incision gonads were excised and fixed in Bouin's solution (24). The histological analysis was conducted after processes of fixation, dehydration, clearing, impregnation and embedding in paraffin. Then tissues were submitted to sectioning and staining (Harris Hematoxylin and Eosin stain (H\&E) Ten randomly selected testicular sections from each rat were analyzed blindly for any disorganization of cytoarchetecture of seminiferous tubules, evidence of vacuoles, gaps and abnormal cells in the seminiferous epithelium and sloughed cells, degeneration of seminiferous epithelium and interstitial spaces in order to achieve qualitative assessment (25).

On the other hand, sections were examined quantitavely (via visopan Reichert, Austria) where the diameter of seminiferous tubules (STD), epithelial height of seminiferous tubules (SEH), mean number of Sertoli cells and Leydig cell were obtained using eyepiece (16), and counted in fifty tubules of each sample at $400 \mathrm{X}$ magnification $(26,27)$.

In addition, Johnsen' scores were used to analyze the effect of drug on spermatogenesis $(28,29)$ The photomicrographs will be captured via Leica microscope with digital camera installed using planapochromatic objectives.

Data were recorded using excel program. Data were analyzed using Microsoft SPSS software version 17. Value is considered as significant when it $\mathrm{P}<0.05$.

\section{Results}

All animals remain alive during the experimental work. At necropsy, no clear gross tissue abnormalities were observed of any animal. The histopathological analysis of the testes of pups that received repeated doses of imatinib at neonatal period or at neonatal /infantile periods showed that the by PND15, loss of differentiated germ cells was shown in testicular sections from treated animals (Figure 1). 


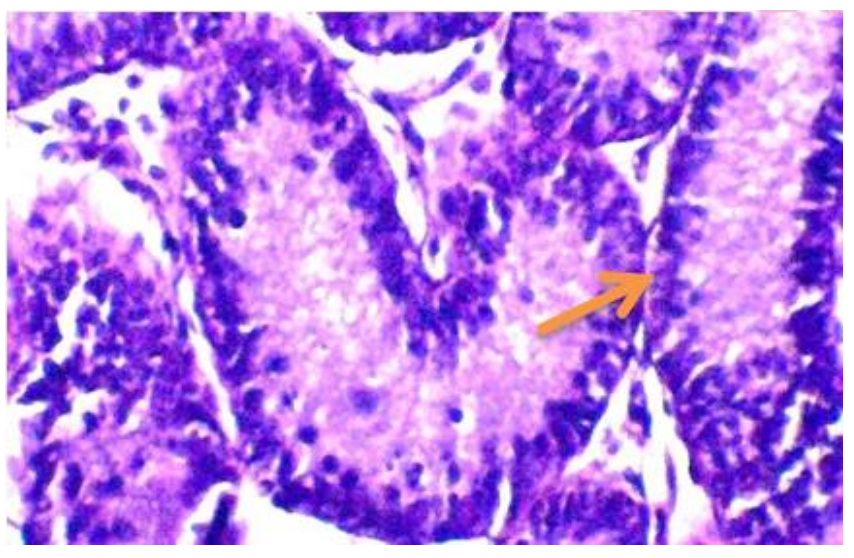

Figure 1: A photomicrograph of a section obtained from rats at PND15 after treatment with $200 \mathrm{mg} / \mathrm{kg} /$ day of imatinib on PND1-PND10, proliferation of spermatogonia is noticed (red arrow) (H\&E×250).

At PND40, sections of control rats showed normal architecture of seminiferous tubule and interstitial tissue (Figure 2). While disturbance in the arrangement of the seminiferous tubules, germ cells depletion, epithelial cells sloughing, intraepithelial cells spaces, an appearance of some multinucleated cells and some apoptotic cells, and interstitial edema were the most evident features of testicular sections of treated animals. Sertoli cell also showed alterations in their morphology in these rats. Their nuclei showed abnormal shape and some of them were far from the basal membrane or even in the tubular lumen. Finally, Sertoli cell only tubular sections were seen (Figure 2) while an appearance of eosinophilic bodies was also noticed in some sections (Figures 2-5) (Table 1).

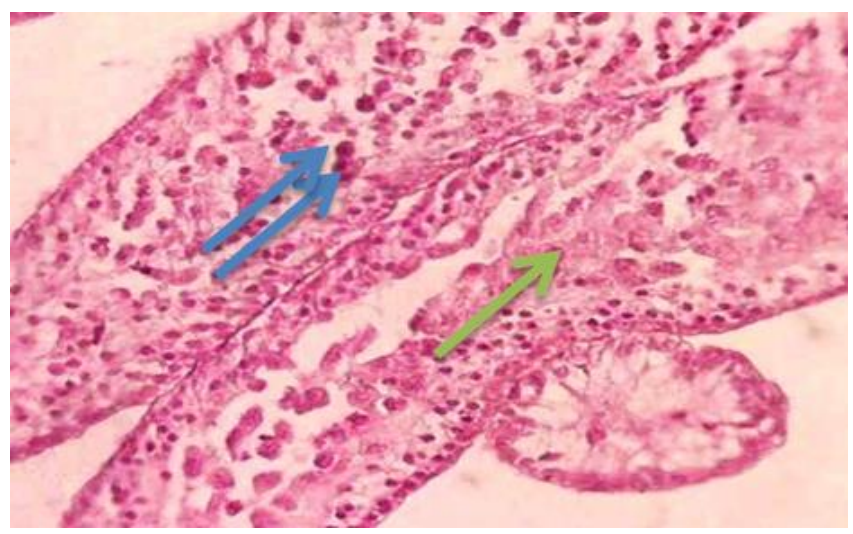

Figures 2: A photomicrograph of a testicular section obtained from rats at PND40 after treatment with $200 \mathrm{mg} / \mathrm{kg} /$ day of imatinib on PND1-PND10 with disturbed seminiferous tubules, depleted germ cells, presence of vacuolated and detached Sertoli cells (green arrow), multinucleated cells (double blue arrow). Sertoli only cells feature is seen in one of the tubules $(\mathrm{H} \& \mathrm{E} \times 250)$.

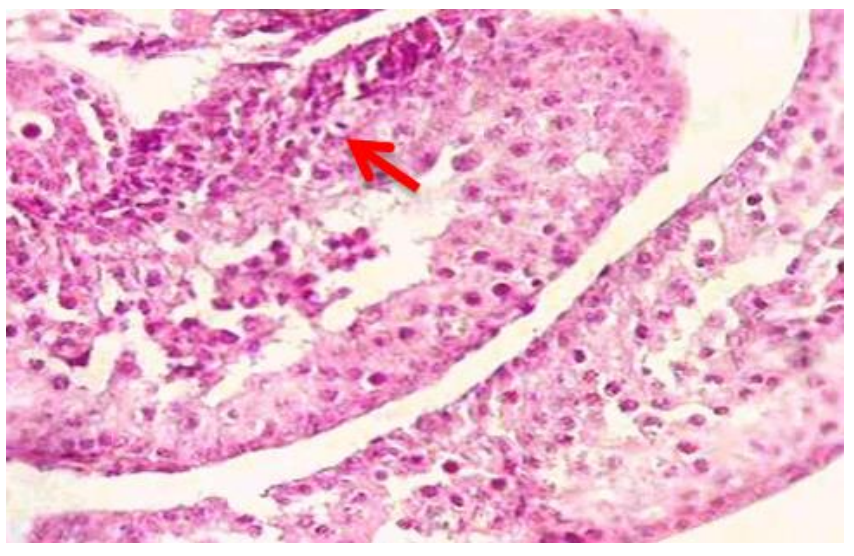

Figures 3: A photomicrograph of testicular section obtained from rats at PND40 after treatment with imatinib on PND1PND10 with disorganized cells and apoptosis (arrow) $(\mathrm{H} \& \mathrm{E} \times 250)$.

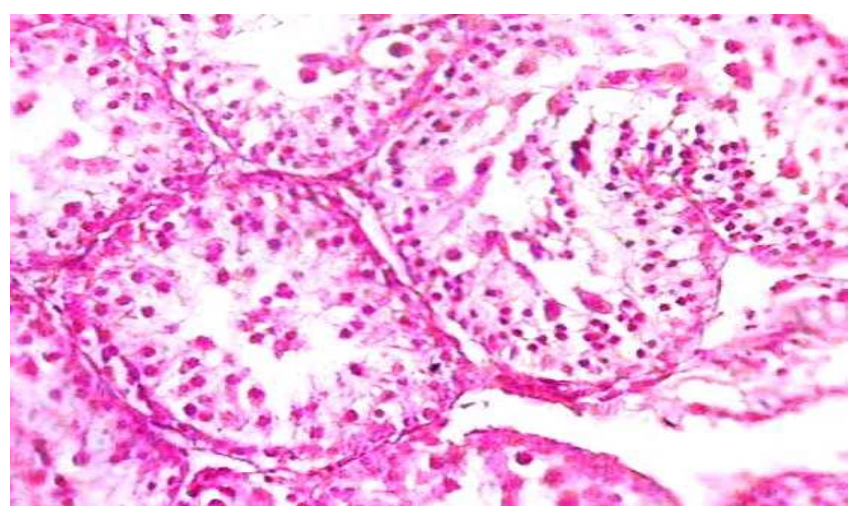

Figure 4: A photomicrograph of a testicular section obtained from rats at PND40 after treatment with $200 \mathrm{mg} / \mathrm{kg} / \mathrm{day}$ of imatinib on PND1-PND10 with germ cells depletion $(\mathrm{H} \& \mathrm{E} \times 250)$.

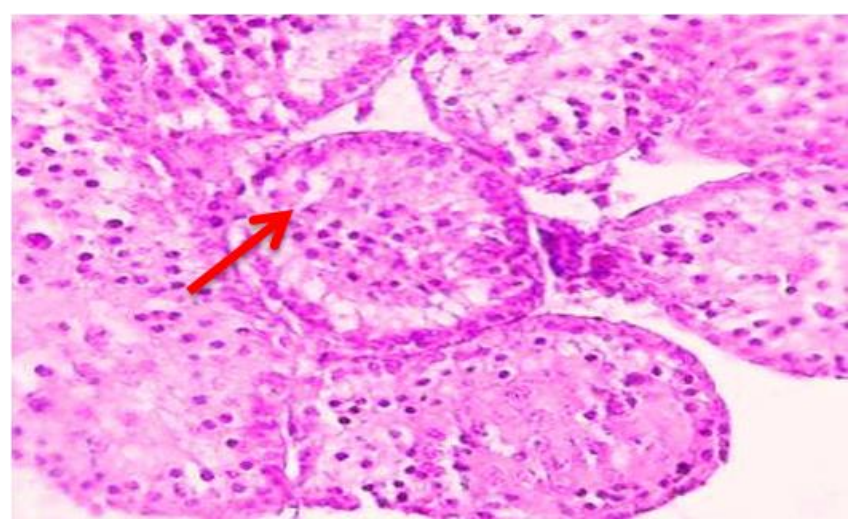

Figure 5: A photomicrograph of a testicular section obtained from rats at PND40 after treatment with $200 \mathrm{mg} / \mathrm{kg} / \mathrm{day}$ of imatinib on PND1-PND10 with vacuolation (arrow) of Sertoli cells $(H \& E \times 250)$. 
In addition, The Seminiferous tubular diameter of this group was significantly reduced mean $117.2 \pm 2.5 \mu \mathrm{m}$. The epithelial height of the tubules was significantly reduced at this group mean $17.3 \pm 3.1 \mu \mathrm{m}$. These sections revealed that mean number of Sertoli cells/seminiferous tubule was 10.5 \pm 2.2 , while that of Leydig cells was 3. $0 \pm 1$. 6., however, some sections exhibited Sertoli only cells feature (Figure 2) (Table 1 and 2).

Qualitatative Analysis of Testicular sections obtained from rats euthanized at PND70 reveals intense several alterations (Table 1). The most obvious features were germ cells loss and sloughing, disorganized appearance of the seminiferous tubules, detachment of some seminiferous tubules from their basement membrane, presence of vacuolated and detached Sertoli cells, some multinucleated cells were noticed, some apoptotic cells were seen, interstitial edema, and retention of elongated spermatid (Figures 6-9). Moreover, histological analysis demonstrated that these animals presented decreased Johnsen's scores in relation to those in control animals (Table 1).

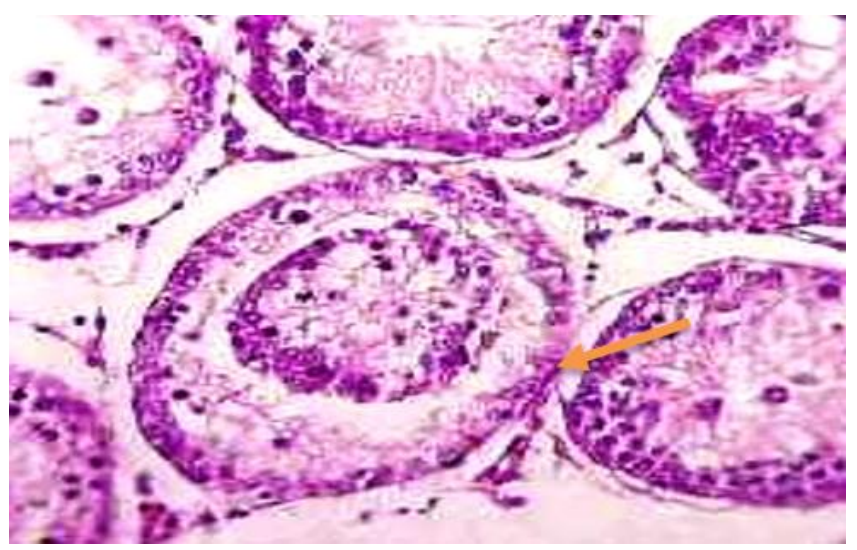

Figure 6: A photomicrograph of a testicular section obtained from rats at PND70after treatment with $200 \mathrm{mg} / \mathrm{kg} / \mathrm{day}$ of imatinib on PND1-PND10 with disorganized appearance of the seminiferous tubules and some multinucleated cells (red arrow). (H\&E×250).

\section{Quantitative analysis}

The seminiferous tubular diameter and their epithelial height of this subgroup at PND70 were diminished in comparison to those in the control rats, with mean of 125 $\pm 4.1 \mu \mathrm{m}$ and $7.0 \pm 1.1 \mu \mathrm{m}$ respectively. Moreover, the number of Sertoli cells per seminiferous tubule was raised with mean of 18.2 \pm 0.2 . Mean Leydig cells number was 7.0 \pm 0.1 (Table 2).

At PND140 the Qualitatative Analysis of testicular sections revealed presence of intraepithelial spaces, sloughing of epithelial cells, arrest at spermatid stage and disorganized appearance of the seminiferous tubules. Johnsen's scores of $5.1 \pm 0.9$ indicated incomplete recovery of spermatogenesis (Figure 10).

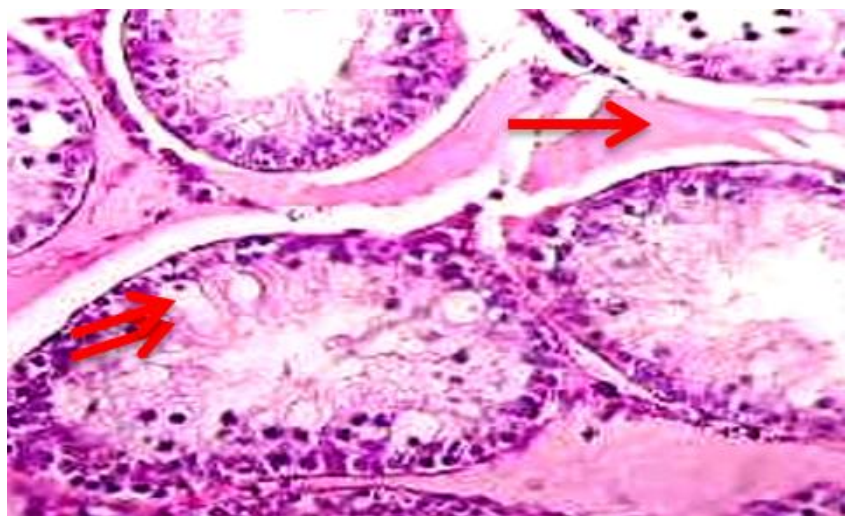

Figure 7: A photomicrograph of a testicular section of rat at PND70 after treatment with $200 \mathrm{mg} / \mathrm{kg} /$ day of imatinib on PND1-PND10 with germ cells depletion, interstitial edema (arrow), and vacuolation (double arrow) (H\&E×250).

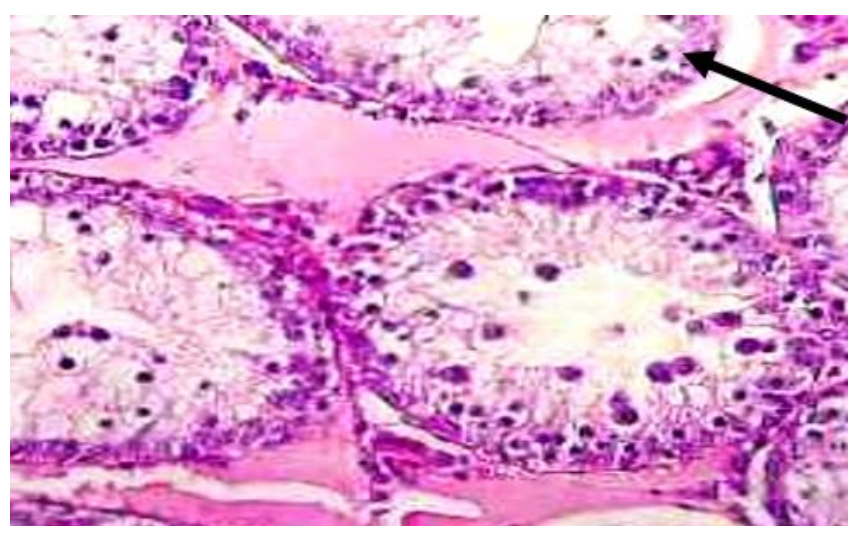

Figure 8: A photomicrograph of a testicular section of rat at PND70 after treatment with $200 \mathrm{mg} / \mathrm{kg} /$ day of imatinib on PND1-PND10 with germ cells depletion, interstitial edema. Detached tubule from their basement membrane (arrow) $(\mathrm{H} \& \mathrm{E} \times 250)$.

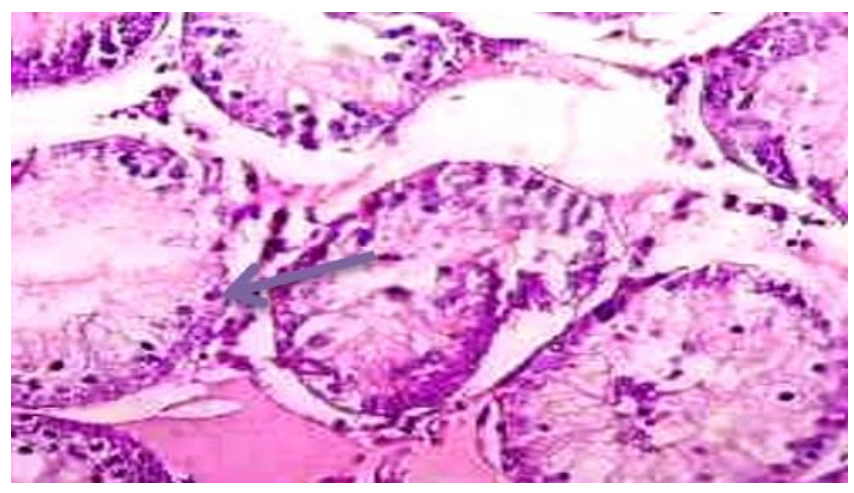

Figure 9: A photomicrograph of a section of rat at PND70 after treatment with of imatinib at PND1-PND10 with disorganization of the seminiferous tubules and germ cells depletion (arrow) (H\&E×250). 
Table 1: early and late term effects of imatinib on testicular histology

\begin{tabular}{|c|c|c|c|c|c|}
\hline \multicolumn{2}{|c|}{ Histological changes } & $\mathrm{P} 40$ & P70 & P140 & P-Value \\
\hline \multicolumn{2}{|c|}{ Disruption of normal cytoarchitecture } & $4(50.0 \%)$ & $5(62.5 \%)$ & $2(25.5 \%)$ & $\mathrm{P}<0.05$ \\
\hline \multicolumn{2}{|c|}{ Depletion of germ cell layer } & $5(62.5 \%)$ & $5(62.5 \%)$ & $2(25.5 \%)$ & $\mathrm{P}<0.05$ \\
\hline \multicolumn{2}{|c|}{ Detachment of germ cell layer } & $4(50.0 \%)$ & $5(62.5 \%)$ & $1(12.5 \%)$ & $\mathrm{P}<0.05$ \\
\hline \multicolumn{2}{|c|}{ Sloughing of germ cells toward the lumen } & $4(50.0 \%)$ & $5(62.5 \%)$ & $2(25.5 \%)$ & $\mathrm{P}<0.05$ \\
\hline \multicolumn{2}{|c|}{ Vacuoles in the germinal layer } & $4(50.0 \%)$ & $5(62.5 \%)$ & $1(12.5 \%)$ & $\mathrm{P}<0.05$ \\
\hline \multicolumn{2}{|c|}{ Multinucleated giant cells } & $3(37.3 \%)$ & $5(62.5 \%)$ & $1(12.5 \%)$ & $\mathrm{P}<0.05$ \\
\hline \multicolumn{2}{|l|}{ Apoptosis } & $3(37.3 \%)$ & $3(37.3 \%)$ & $1(12.5 \%)$ & $\mathrm{P}<0.05$ \\
\hline \multicolumn{2}{|c|}{ Degenerated seminiferous tubules } & $1(12.5 \%)$ & $2(25.5 \%)$ & $1(12.5 \%)$ & $\mathrm{P}>0.05$ \\
\hline \multicolumn{2}{|c|}{ Thick basement membrane } & $1(12.5 \%)$ & $2(25.5 \%)$ & $1(12.5 \%)$ & $\mathrm{P}>0.05$ \\
\hline \multirow{4}{*}{$\begin{array}{c}\text { Sertoli cell } \\
\text { abnormalities }\end{array}$} & Vaculation & $3(37.3 \%)$ & $4(50.0 \%)$ & $1(12.5 \%)$ & $\mathrm{P}<0.05$ \\
\hline & Non-nucleated $\mathrm{S}$ cell & $3(37.3 \%)$ & $4(50.0 \%)$ & $1(12.5 \%)$ & $\mathrm{P}<0.05$ \\
\hline & Detached cell & $3(37.3 \%)$ & $4(50.0 \%)$ & $1(12.5 \%)$ & $\mathrm{P}<0.05$ \\
\hline & Sertoli only cell syndrome & $1(12.5 \%)$ & $0(0.0 \%)$ & $0(0.0 \%)$ & $\mathrm{P}>0.05$ \\
\hline \multirow{3}{*}{ Tunica albuginea } & Thick Tunica albuginea & $1(12.5 \%)$ & $1(12.5 \%)$ & $0(0.0 \%)$ & $\mathrm{P}<0.05$ \\
\hline & Dilated blood vessels & $1(12.5 \%)$ & $1(12.5 \%)$ & $0(0.0 \%)$ & $\mathrm{P}<0.05$ \\
\hline & Interstitial edema & $3(37.3 \%)$ & $5(62.5 \%)$ & $1(12.5 \%)$ & $\mathrm{P}<0.05$ \\
\hline \multirow{3}{*}{ Interstitial space } & Inflammatory cells & $0(0.0 \%)$ & $0(0.0 \%)$ & $0(0.0 \%)$ & $\mathrm{P}>0.05$ \\
\hline & Congested blood vessels & $1(12.5 \%)$ & $1(12.5 \%)$ & $1(12.5 \%)$ & $\mathrm{P}>0.05$ \\
\hline & Hemorrhage & $0(0.0 \%)$ & $0(0.0 \%)$ & $0(0.0 \%)$ & $\mathrm{P}>0.05$ \\
\hline \multicolumn{2}{|l|}{ Johnsen's Scores } & & 4. $5 \pm 0.4$ & 5. $1 \pm 0.9$ & $\mathrm{P}>0.05$ \\
\hline
\end{tabular}

*P-value is considered as significant when $\mathrm{P}<0.05$.

Table 2: Effects of imatinib on some testicular morphological parameters at various endpoints

\begin{tabular}{lcccc}
\hline Parameter & P40 & P70 & P 140 & P-Value \\
\hline Diameter of the seminiferous tubules $(\mu \mathrm{m})$ & $117.5 \pm 2.5$ & $125 \pm 4.1$ & $185 \pm 2.1$ & $\mathrm{P}<0.05$ \\
Height of the epithelial layer $(\mu \mathrm{m})$ & $17.3 \pm 3.1$ & $7.0 \pm 1.1$ & $60 \pm 2.1$ & $\mathrm{P}<0.05$ \\
Sertoli cell /Seminiferous tubule & $10.5 \pm 2.2$ & $18.2 \pm 0.2$ & $12.9 \pm 0.3$ & $\mathrm{P}<0.05$ \\
Leydig cell & $3.0 \pm 1.6$ & $7.0 \pm 0.1$ & $5.0 \pm 0.9$ & $\mathrm{P}<0.05$ \\
\hline
\end{tabular}

*P-value is considered as significant when $\mathrm{P}<0.05$.

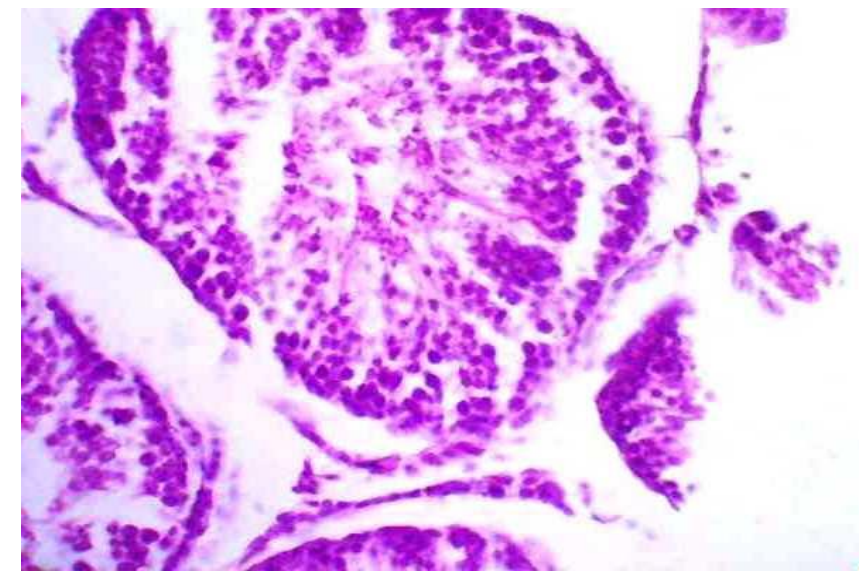

Figure 10: A photomicrograph of a testicular section of rat at PND140 treated with imatinib at PND1-PND10 with disorganization of the seminiferous tubules and germ cells depletion (H\&E×400).

\section{Quantitative analysis}

The seminiferous tubular diameter and their epithelial height of this subgroup were reduced if compared with those in the control rats, with mean of $185 \pm 2.1 \mu \mathrm{m}$ and $60.3 \pm 2.1$ $\mu \mathrm{m}$ respectively. Moreover, the mean number of Sertoli cells/ seminiferous tubule is $12.9 \pm 0.3$. Mean Leydig cells number was 5.0 \pm 0.9 (Table 2).

\section{Discussion}

Recently imatinib is the only TKI that is used for pediatric patients. It was choosen in treatment of children with $\mathrm{Ph}+\mathrm{CML}$ that labels for only for $2 \%$ of all leukemia in children. It is also accounted to manage pediatric GIST tumors (30). Answering the question if these new agents result harmful effects on the reproductive system at its development is a critical aspect of preclinical drug stages, especially if the agent is to be entitled for in patients with young. Ages. However, testing for a chronic term impact on testicular histology in some mammals in vivo is not simple, 
even in rats, very frequently used animals to explore its toxic effects (6).

In this study morphological analysis of testicular sections was performed to clarify if imatinib makes a disturbance in the development of the spermatogonial stem cell pool. In control group, the centrally localized germ cells transfer to the basement membrane throughout the 1st postnatal days and forming a spermatogonial stem cell pool. The current work showed that repeated imatinib dosing starting on postnatal days $1-10(200 \mathrm{mg} / \mathrm{kg} /$ once/day/10) prevented this migration and subsequently, significantly diminished number of peripheral germ cells. Further, germ cells localized at center underwent proliferation in adluminal parts and the number of centrally localized germ cells raised in sections of pups at PND15. These findings are similar to those of Basciani et al. (31) who attributed that to apoptosis in germ cells. Different histological changes were more frequent in sections obtained from rats euthanized at PND40 and at PND70, these findings are similar to those of other workers, who reported that prepubertal doxorubicin administration induce adverse effects on testicular histology at age of seventy postnatal days (32). This study showed that the persistence of harmful effects on rats after treatment at neonatal or early infantile period is similar to other studies which attributed that to the irreversible inhibition of TKR, ckit and PDGFR which induces disturbance in migration (33), proliferations and the survival (34) of germ cells. Further, PDGFR-mediated proliferation of peritubular myoid cells was prevented leading to decreased growth of the seminiferous tubules longitudinally. Concerning that in humans gonocytes migration is mainly finished at birth, the impact of imatinib on somatic stem cells and spermatogonia, the liable or possible cellular galls for younger males during imatinib therapy, has remained a critical and challenging issue $(32,35)$.

Irreversible damage happens if Sertoli cells cannot provide a support for stem cell spermatogonia or if the whole stem cell spermatogonia number is reduced. While the impacts of cancer therapy become immediately identifiable in the testes of adults, the sequel of such treatments in immature males are remaining not obvious till puberty. Recently, exploration of gonadal damages cannot be done prior to this $(6,35)$.

One of the changes associated with imatinib treatment is the appearance of multinucleated cells which are present in sections of $3(37.3 \%), 5(62.5 \%)$ rats at PND40, PND70 respectively. These findings are in accordance with those of another author (17) and those of Cerebasi et al (36), who considered formation of multinucleated cells in testicular sections of rats after administration with 5-flurouracil and cyclophosphamide respectively as a marker of testicular injury $(36,37)$.

To our knowledge the mechanisms of formation, shape and fate of abnormal germ cells have not been previously demonstrated in imatinib treated animals. Authors discussed the pathogenesis of these cells in rat testis exposed to 5-FU, and they reported that multinucleated cells were present in the seminiferous epithelium, tubular lumen and exhibited a positive correlation between the number these cells and epithelial sloughing. The present work showed the appearance of fusion of nuclei, which may represent the continuous process of cell fusion in the epithelium, these findings are in accordance with those of other authors (36) who exposed rats to cyclophosphamide. On the other hand, esinophilic bodies in some testicular section from imatinib treated rats were shown. These findings are similar to those of other researchers $(17,37)$. They revealed that some of multinucleated cells appeared as empty spaces after treatment with 5-FU as this agent induced cytotoxicity by inducing effects on RNA or DNA and cell cycle arrest, leading to development of abnormal germ cell and disorientation of spermatids in the testis of rats and sloughing of epithelium, while others reported the presence of similar lesion after treatment of rats with doxorubicin treatment during pre-pubertal phase (33).

Imatinib induced epithelial sloughing in testicular sections of rats when administered at peri-puberty (19), this work revealed that $4(50 \%)$ out of 8 rats, $5(62 \%)$ out of 8 rats exhibited the same findings in rats treated with imatinib at pre-puberty and euthanized at PND40, PND70 respectively. This sloughing as may be due to various factors (21). Authors suggested that it is greatly due to the damage of Sertoli cell and blocking of intercellular bridges and reported that sloughed spermatids may fuse together to form the multinucleated cells (19). The appearance of eosinophilic bodies in a section from imatinib treated rats in the present work, may be explained as the multinucleated cells may suffer from degeneration of their nuclei and gradually disappeared and left PAS positive bodies with well identified borders. In addition, Imatinib has expected alterations and speculative influences cell cycle progression by $\mathrm{Cdc}_{2}$ inhibition as reported by others (38) that may explain its role in formation of multinucleated cells and epithelial sloughing in the rat testis.

On the other hand, the changes observed in sertoli cells were more evident in PND70. A similar observation was reported by others (32). Their data showed that doxorubicin exposure throughout prepuberty causes morphological long term damage to Sertoli cells; such effect happened after the germ cell primary injury and shared in enhancement of the spermatogenic deleterious effects induced by drug. In addition, there was a slightly raising number of elongated spermatids in the rats administered with imatinib comparing to those of controls. These findings are in accordance with those of others $(32,35)$. Regarding the quantitative analysis of testicular sections after administration with imatinib at neonatal and early infantile period, this study revealed a diminishing in the diameter of the seminiferous tubules, height of the epithelial layer especially at PND70. 
There is one study on the hitomorphometric analysis after treatment with imatinib at the neonatal period (33) which reported absence of significant alterations in the seminiferous tubular diameter or in epithelial thickness and this difference may be due to the individual variation. However, similar observations were noticed in that study of Nurmio regarding the number of Sertoli cells as the number of Sertoli cells /cord cross section increased at PND70 as in our study as Sertoli cells do not show an expressing of c-kit or PDGFR receptors, so, Sertoli cells undergo proliferation as in normal states (35). Although the present study used the rat as an animal model, immature human testes is also susceptible to the impact of imatinib since c-kit is reported to show an expression in human testis at prepuberty (39) and the mode of expression of the PDGF receptor in human fetus and adult testicular section is similar to that in rats (31).

It has been reported (in our previous work) that the recovery of rat testes after administration of imatinib at peripuberty is better than that in those treated with imatinib in prepubertal phase (19). As shown in this study, partial recovery was noticed at PND140. These observations are similar to those of previous studies which concluded that the prepubertal testes are more susceptible to the effects of imatinib and doxorubicin respectively $(40,41)$ Our observations showed that imatinib induced (to some extent) late term adverse effect on testicular histology.

\section{Conclusion}

Imatinib has short and long term effects on testicular histology after exposure at pre-pubertal period and the induced histological changes were more obviously seen in sections of rats euthanized at P40 and at P70. A milder recovery was noticed at P140 indicating that the pre-pubertal testes are more vulnerable to the effects of imatinib and reflects its age dependency. Future studies should be recommended regarding the exploring effects of this drug on other components (Sertoli and Leydig cells) using immunohistochemistry and TEM. Late -term evaluation of the agents at clinically relevant doses and applying valid experimental models are necessary especially for novel ones.

\section{Acknowledgment}

Authors are grateful to all members of Ibn- Sena Teaching Hospital for their help in facilitating this study. Our thanks are to the staff of Animal house in Mosul medical college for their help to accomplish this work. Special thanks are also to the Deputy Minister of Ministry of high education and scientific research /Iraq, Professor, Dr. Fouad Kassim Mohammad for his excellent comments. We are also grateful to Assistant Professor, Dr. Mohammed Shindal, and Assistant Professor, Dr. Banan Al-Baghoo, Department of Pharmacology, College of Veterinary Medicine, University of Mosul for their helpful comments.

\section{Conflict of interest}

Authors declared that there is no conflict of interest.

\section{References}

1. Howell SJ, Shalet SM. Spermatogenesis after cancer treatment: damage and recovery. J Natl Cancer Inst Monogr. 2005;34:12-17. Doi: 10.1093/jncimonographs/lgi003

2. Stiller CA. Epidemiology and genetics of childhood cancer. Oncogene. 2004;23:6429-6444. Doi: 10.1038/sj.onc. 1207717

3. Gambacorti-Passerini C, Tornaghi L, Cavagnini F. Gynaecomastia in men with chronic myeloid leukaemia after imatinib. Lancet. 2003;361(3):1954-1956. Doi: 10.1016/S0140-6736(03)13554-4

4. Herman EH, Knapton A, Rosen E, Thompson K, Rosenzweig B, Estis J, Agee S, Lu QA, Todd JA, Lipshultz S, Hasinoff B, Zhang J. A multifaceted evaluation of imatinib-induced cardiotoxicity in the rat. Toxicol Pathol. 2011;39(7):1091-1106. Doi: 10.1177/0192623311419524

5. Sawyers CL. Opportunities and challenges in the development of kinase inhibitor therapy for cancer. Genes Dev. 2003;17:2998-3010. Doi: 10.1101/gad.1152403

6. Heim, C. Minniear, K. Dann, C. Imatinib has deleterious effects on differentiating spermatogonia while sparing spermatogonial stem cell self-renewal. Reprod Toxicol. 2011;31(4):454-463. Doi: 10.1016/j.reprotox.2010.12.056

7. Krause DS, VanEtten RA. Tyrosine kinases as targets for cancer therapy. N Eng1 J Med. 2005;353:172-187. Doi: 10.1056/NEJMra044389

8. Braconi C, Bracci R, Cellerino R. Molecular targets in gastrointestinal stromal tumors (GIST) therapy. Curr Cancer Drug Targets. 2008;8:359366. Doi: $\underline{10.2174 / 156800908785133169}$

9. Sawyer DB, Zuppinger C, Miller TA, Eppenberger HM, Suter TM. Modulation of anthracycline-induced myofibrillar disarray in rat ventricular myocytes by neuregulin-1b and anti-erbB2: potential mechanism for trastuzumab-induced cardiotoxicity. Circulation. 2002;105:1551-1554. Doi: $10.1161 / 01$.cir.0000013839.41224.1c

10. Pou M, Saval N, Vera M, Saurina A, Solé M, Cervantes F, Botey A. Acute renal failure secondary to imatinib mesylate treatment in chronic myeloid leukemia. Leuk Lymphoma. 2003;44:1239-1241. Doi: $10.1080 / 1042819031000079140$

11. Foringer JR, Verami RR, Tjia VM. Acute renal failure to imatinib mesylate treatment in prostatecancer. Ann Pharmaco. 2005;39:21362138. Doi: $10.1345 / a p h .1 G 131$

12. Cross TJ, Bagot C, Portmann B, Wendon J, Gillett D. Imatinib mesylate as a cause of acute liver failure. Am J Hematol. 2006;81:189-192. Doi: 10.1002/ajh.20486

13. Wolf A, Couttet P, Dong M, Grenet O, Heron M, Junker U, Laengle U, Ledieu D, Marrer E, Nussher A, Persohn E, Pognan F, Rivie`re GJ, Roth DR, Trendelenburg C, Tsao J, Roman D. Imatinib does not induce cardiotoxicity at clinically relevant concentrations in preclinical studies. Leuk Res. 2010;34(9):1180-1188. Doi: 10.1016/j.leukres.2010.01.004

14. Kim H, Chang HM, Ryu MH. Concurrent male gynecomastia and testicular hydrocele after imatinib mesylate treatment of a gastrointestinal stromal tumor. J Korean Med Sci. 2005;20(3):512-515. Doi: $\underline{10.3346 / \mathrm{jkms} .2005 .20 .3 .512}$

15. Favareto APA, Fernandez CDB, Fossato da Silva DA. Persistent impairment of testicular histology and sperm motility in adult rats treated with cisplatin at peripuberty. Basic Clin Pharmacol Toxicol. 2011;109:85-96. Doi: 10.1111/j.1742-7843.2011.00688.x

16. Ilbey YO, Ozbek E, Cekmen M. Protective effect of curcumin in cisplatin-induced oxidative injury in rat testis: mitogen-activated protein kinase and nuclear factor-kappa B signaling pathways. Hum Reprod 2009;24(7):1717-25. Doi: 10.1093/humrep/dep058

17. D'Souza UJA. Toxic effects of 5-fluorouracil on sperm count in wistar rats. Malaysian J Med Sciences. 2003;10(1):43-45. 
18. Mohan M, Bhandare S. Protective effect of Solanum torvum against testiculat toxicity in male wistar rats. Int J Pharm Pharmaceut Sci. 2012;4(3):188-92. Doi: 10.1016/j.fct.2009.10.042

19. Al-Allaf LI, Al-Ashoo HA. The effects of imatinib on the testicular histology in male rats administered at peripubertal period. JABHS. 2014;15(1):24-34.

20. Nurmio M, Kallio J, Toppari J, Jahnukainen K. Adult reproductive functions after early postnatal inhibition by imatinib of the two receptor tyrosine kinases, c-kit and PDGFR, in the rat testis. Reprod Toxicol. 2008;25(4):442-446. Doi: 10.1016/j.reprotox.2008.03.004

21. Kerkela R, Grazette L, Yacobi R. Cardiotoxicity of the cancer therapeutic agent imatinib mesylate. Nat Med. 2006;12(8):908-916. Doi: $10.1038 / \mathrm{nm} 1446$

22. Bachmann K, Pardoe D, White D. Scaling basic toxicokinetic parameters from rat to man. Environ Health Perspect 1996;104:400407. Doi: 10.1289/ehp. 96104400

23. Saad SY, Alkharfy KM, Arafah MM. Cardiotoxic effects of arsenic trioxide/imatinib mesilate combination in rats. JPP 2006;58:1-7. Doi: 10.1211/jpp.58.4.0017

24. Afify M, Abd Elmaksoud MD, Mosa T. Differential effects of amitriptyline treatment on testicular and liver functions in adult male rats. New York Science J. 2010;3(3):10-18.

25. Prasad AM, Ramnarayan K, Bairy KL. Effect of imatinib on histological parameters in albino mice. J Pharmaceut Sciences Rev Res. 2010;4(2):117-122

26. Yaghmaei P, Parivar K, Gharibi A, Nabiuni M. The biological effects of imatinib on male fertility of wistar rats. IJFS. 2009;3(3):135-142.

27. Ramos SDP, Goessler KF, Ruiz RJ, Ferrari O, Polito MD, Sparça Salles MJ. Exercise protects rat testis from cyclophosphamide-induced damage. Acta Biol Sci. 2013;35(1):105-113. Doi: 10.4025 /actascibiolsci.v35i1.12475

28. Johnsen SG. Testicular biopsy score count - a method for registration of spermatogenesis in human testes: Normal values and results in 335 hypogonadal males. Hormones. 1970;1:2-25.

29. 29. Rosai and Ackerman's. Surgical pathology. $10^{\text {th }}$ edition. London: Mosby; 2011. 1287-1383 p.

30. Kuroiwa M, Hiwatari M, Hirato J, Suzuki N, Tsuchida Y, Shimada A, Shitara T, Taki T, Hayashi Y. Advanced-stage gastrointestinal stromal tumor treated with imatinib in a 12-year-old girl with a unique mutation of PDGFRA. J Pediatr Surg. 2005;40:1798-1801. Doi: $10.1016 /$ j.jpedsurg.2005.07.066

31. Basciani S, De Luca G, Dolci S, Brama M, Arizzi M, Mariani S. Platelet-derived growth factor receptor beta-subtype regulates proliferation and migration of gonocytes. Endocrinol. 2008;149:62266235. Doi: $10.1210 /$ en.2008-0349

32. Brilhante O, Okada FK, Sasso-Cerri E, Stumpp T, Miraglia S M. Late morfofunctional alterations of the Sertoli cell caused by doxorubicin administered to prepubertal rats. Reproductive Biology and Endocrinology. 2012;10:79. Doi: 10.1186/1477-7827-10-79

33. Nurmio M, Toppari J, Zaman F, Andersson AM, Paranko J, Soder O. Inhibition of tyrosine kinases PDGFR and C-Kit by imatinib mesylate interferes with postnatal testicular development in the rat. Int J Androl. 2007;30:366-376. Doi: 10.1111/j.1365-2605.2007.00755.x

34. Yan W, Suominen J, Toppari J. Stem cell factor protects germ cells from apoptosis in vitro. J Cell Sci. 2000;113(1):161-168.

35. Nurmio M. Cancer therapy-related toxicity in the immature testis [MSc thesis]. Turku: Departments of Physiology and Paediatrics, Institute of Biomedicine, University of Turku, Turku, Finland; 2009. 20-55 p.

36. Ceribasi AO, Turk G, Sçnmez M, Sakin F, Ateahin A. Toxic effect of cyclophosphamide on sperm morphology, testicular histology and blood oxidant-antioxidant balance, and protective roles of lycopene and ellagic acid. Basic Clin Pharmacol Toxicol. 2010;107:730-736. Doi: 10.1111/j.1742-7843.2010.00571x

37. D‘Souza UJA, Narayana K. Formation, morphology and fate of multinucleated cells (symplasts) in the rat testis exposed to 5fluorouracil. Indian J Physiol Pharmacol. 2002;46(4):504-506.
38. Cheng $\mathrm{H}$ and Force T. Molecular mechanisms of cardiovascular toxicity of targeted cancer therapeutics. Circ Res. 2010;106:21-34. Doi: 10.1161/CIRCRESAHA.109.206920

39. Nicotina PA, Romeo C, Arena S, Impellizzeri P, Antonuccio P, Arena F, Zuccarello B, and Romeo G. Immunohistology of aquaporin-1 and stem cell factor-receptor in human undescended testes. Pediatr Surg Int. 2004;20:271-275. Doi: 10.1007/s003833-1125-Z

40. Abdullah BA, Alfahad M, Hdree DK. Effects of red reishi mushroom (Ganoderma lucidum) on the reproductive system in female and male rats. Iraqi J Vet $\quad$ Sci. 2019;33(1):137141. Doi: $10.33899 /$ ijvs.2019.125547.1067

41. Jasem HM, Abdul Alrasool EM, Hassan AA. Effect of cadmium on CNS function and development in rat offspring: Effect of vitamin $\mathrm{E}$. Iraqi J Vet Sci. 2008;22(1):31-37. Doi: 10.33899/ijvs.2008.5658

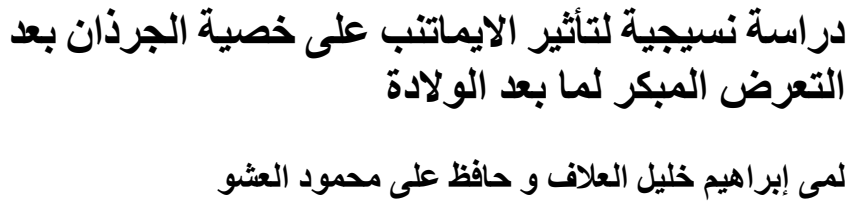

فرع التشريح، كلية طب الموصل، جامعة الموصل، الموصل، العراق

الخلاصة

إن الحيز الأمن للايماتتب وخاصة إمكانية حدوث سمية في الخصيتين

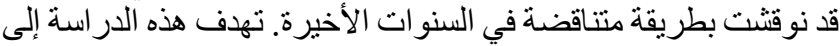
تقييم انعكاس تعرض ذكور الجرذان البيض للايماتتب في مرحلة حديثي

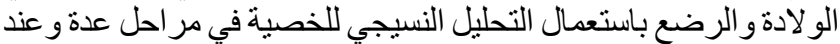

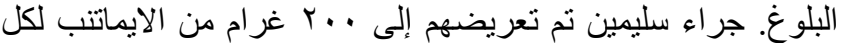

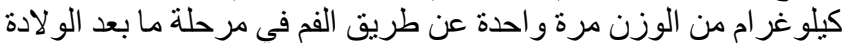

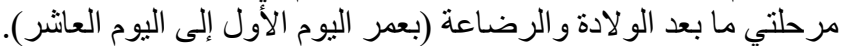

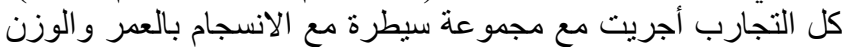

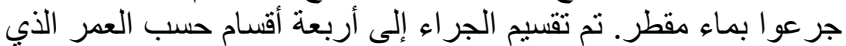

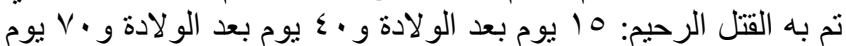

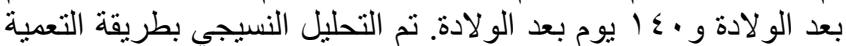

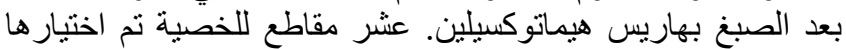

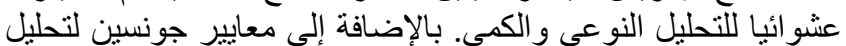

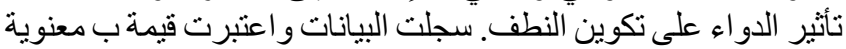

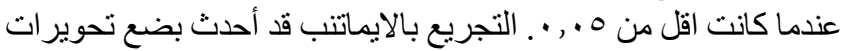

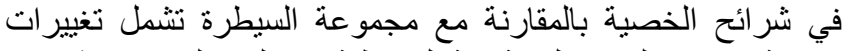

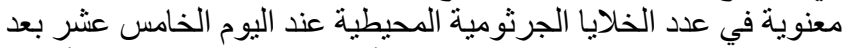

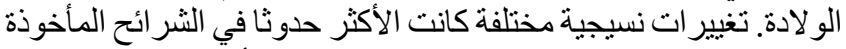

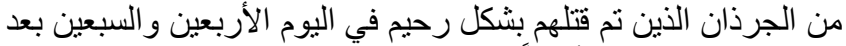

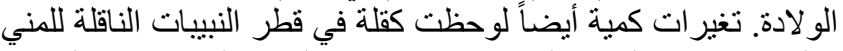

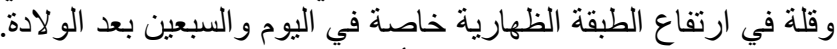

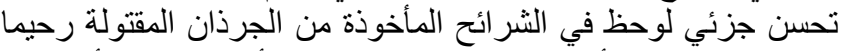

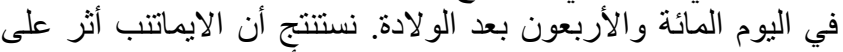

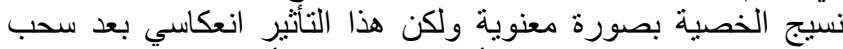
الدواء. هذه الاستتناجات ممكن أن تساعد الطبيب أن يخطط ولئ ولينتبه لقضايا

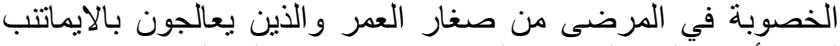
لعلاج أورام القناة المعدية والهضية فية وابيضناض الدم المزمن. 